\title{
Soil erosion assessment on tillage and alternative soil managements in a Sicilian vineyard
}

\author{
A. Novara ${ }^{\text {a,* }}$, L. Gristina ${ }^{a}$, S.S. Saladino ${ }^{\text {a }}$, A. Santoro ${ }^{\text {a }}$, A. Cerdà ${ }^{\mathrm{b}}$ \\ a Dipartimento dei Sistemi Agro-ambientali - Viale delle Scienze - 90128, Palermo, Italy \\ ${ }^{\mathrm{b}}$ Department de Geografia, Universitat de València, Blasco Ibáñez, 28, 46010 Valencia, Spain
}

\section{A R T I C L E I N F O}

\section{Article history:}

Received 10 June 2011

Received in revised form 23 September 2011

Accepted 25 September 2011

Available online 22 October 2011

\section{Keywords:}

Cover crops

Mediterranean

Soil erosion control

Vineyard

Sicily

\begin{abstract}
A B S T R A C T
Mediterranean crops favor high erosion rates. Vineyards use to reach the highest soil and water losses due to the lack of vegetation cover. A topographical approach by means of the use of vineyards poles as fixed reference point as erosion markers allowed to quantify high and non-sustainable soil erosion rates on the Sicilian vineyards during 9 years. In order to develop strategies to control the soil losses, seven land managements were selected and applied in a typical blanc wine grape irrigated vineyard located in southwestern Sicily. Comparable plots were managed traditionally using conventional tillage and alternatively using various cover crops: (1) Vicia faba; (2) V. faba and Vicia sativa; (3) Trifolium subterraneum, Festuca rubra, and Lolium perenne; (4) T. subterraneum, F. rubra, and Festuca ovina; (5) Triticum durum; and (6) T. durum and $V$. sativa. To estimate the soil losses the $C$ factor of the USLE was calculated. And to monitor the water and sediment yield, Gerlach troughs were installed on the vineyard inter-row. Runoff and erosion were measured after each rainfall event from November 2005 to April 2007. Both runoff and erosion were significantly reduced when cover crops of T. subterraneum, F. rubra, and L. perenne; and T. subterraneum, F. rubra, and $F$. ovina were sown. The least effective management systems for soil erosion were conventional tillage and alternative management using the $V$. faba cover crop. Our results suggest that planting the appropriate cover crops provides an effective soil and water management system for Sicilian vineyards which will make sustainable the wine and grapes production under Mediterranean climate conditions.
\end{abstract}

(C) 2011 Elsevier B.V. All rights reserved.

\section{Introduction}

Soil erosion processes are highly active on agriculture land (Cerdà et al., 2007, 2009). Soil in Mediterranean-type ecosystems causes land degradation and triggers desertification (Oldeman, 1994; Shrestha et al., 2004; Cerdà et al., 2010). Mediterranean lands are particularly prone to soil erosion due to high rainfall intensity, the steep slopes, soil poor nutrient content and low organic matter. Moreover, the amount of organic matter is closely related to the formation of aggregates which are a key factor on soil erodibility (Cerdà, 1996; Le Bissonnais and Arrouays, 1997). Organic matter loss causes soil aggregates to break down easily and increases soil erodibility (Wu and Tiessen, 2002; Cantón et al., 2009). Soil erosion depends not only on soil characteristics, climate, and slope (Ruiz Sinoga and Martinez Murillo, 2009), but also on land use and cover plants (García-Ruiz, 2010). In the Mediterranean, in particular, vineyards on hilly areas have the highest measured soil losses compared to rainfed cereals, olives, eucalyptus plantation or scrubland (Kosmas et al., 1997). Such high

\footnotetext{
* Corresponding author. Tel.: +39 3206983438.

E-mail address: agata.novara@unipa.it (A. Novara).
}

erosion rates are primarily attributable to: (i) the bare soil under the vines for most of the year, especially during the rainy season; and (ii) the planting of vine rows along the fall line, which creates more favorable conditions for water runoff and sediment loss.

The range of soil erosion rates in vineyards is diverse due to the different land managements, climate conditions, parent material and soil properties, but generally the soil and water losses are usually high and always non-sustainable. De Santisteban et al. (2006) measured rates from 3.3 to $161.9 \mathrm{Mg} \mathrm{ha}^{-1}$ year $^{-1}$, depending primarily on the soil management systems. In vineyards, the most common soil management systems are tillage and chemical weeding with no tillage. Both systems result in bare soil during the whole year. Lasanta and Sobrón (1988) estimated that only 5\% of the ground in an old vineyard is covered by cover plants during the rainy season and several studies under different environmental conditions have shown positive effects of vegetative cover for reducing water erosion (Cerdà, 1998). Cover crops increase infiltration of winter rain into the soil profile (Folorunso et al., 1992; Gulick et al., 1994). Vegetation also protects the soil surface from the impact of raindrops, reduces the energy of runoff, and stimulates the formation and stabilization of soil aggregates (Bouchet et al., 1999; Mataix-Solera et al., 2002; García-Orenes et al., 2005; Durán-Zuazo and Rodríguez-Plequezuelo, 2008). 
Switching from conventional tillage to alternative cover crop management practices in autumn and winter reduce soil erosion and enhance the organic matter and microbiological function of soil (Quinton and Catt, 2004; Steenwerth and Belina, 2008; GarcíaOrenes et al., 2009, 2010). In Sicily, experimental cover crop soil management suggests a benefit only during the fall and winter grape dormancy period, with cover crops being removed and buried no later than April to avoid such competition (Gristina et al., 2006).

To monitor and predict the extent of soil degradation and to improve soil management and soil conservation planning is essential the quantification of sediment yield (Boardman and Poesen, 2006; Gristina et al., 2005). Soil erosion assessment by means of experimental plots use to measure the soil losses during short periods of time. This is fundamental to understand soil erosion processes and their spatial and temporal variability. Under Mediterranean climatic conditions, where the erosion processes are controlled by the high magnitude - low frequency rainfall events the measurements on experimental plots use to do not show the long term soil losses. To measure the soil losses during a long period of time contribute to a better understanding of the soil erosion processes and is complementary to the measurements done in plots. In the present study, we propose the use of simple poles as fixed reference points against which soil loss is readily monitored and erosion rates in a longer period are easily determined simply by measuring the over-ground height of the poles. Using the plot method, we compare the effects of various cover crops and conventional tillage on soil erosion rates in vineyards. The purposes of this paper are: (i) to assess erosion rates during a 9-year period using vineyard poles as markers and (ii) to evaluate the role of conservative and alternative soil management in vineyards to control erosion risk testing the effectiveness of different cover crops. The comparison of the longer period and two-year data will shed light on the significance of these measurements.

\section{Materials and methods}

\subsection{Study area}

The research was conducted in irrigated vineyards located in Sambuca di Sicilia, in southwestern Sicily $\left(37^{\circ} 39^{\prime} 17^{\prime \prime} \mathrm{N}\right.$ and $13^{\circ} 00^{\prime}$ $\left.53^{\prime \prime} \mathrm{E}\right)$. The vineyards selected for the study lie between 350 and 373 m.a.s.l.; the plot is located in an ENE facing slope. The climate in the area is typical Mediterranean with dry, hot summers and moist winters. Precipitation data from Sciacca weather station located $6 \mathrm{~km}$ from the site were used. Mean annual rainfall is $648 \mathrm{~mm}$ and means annual temperature is $17.4^{\circ} \mathrm{C}$ with the mean monthly maximum in August $\left(26.2^{\circ} \mathrm{C}\right)$ and minimum in January $\left(9.7^{\circ} \mathrm{C}\right)$. Fig. 1 shows the mean temperature and rainfall for the period of runoff observation. From the implantation of the vines to 2010 the mean rainfall was $589 \pm 175 \mathrm{~mm}$. Soil was classified as Vertic Haploxerept according to Soil Taxonomy (Soil Survey Staff, 2006) with $58.3 \pm 2.5 \%$ sand, $11 \pm 1.47 \%$ silt, and $30.7 \pm 2.32 \%$ clay (pipette method; Day, 1965) in the top soil $(0-20 \mathrm{~cm})$. The average organic carbon content was determined following the Walkley and Black (1934) method, is $7.81 \mathrm{~g} \mathrm{~kg}^{-1}$.

\subsection{Experimental design}

The research was carried out in a 9-year-old vineyard of the Sauvignon blanc variety on a wet regime with a density of 5000 plants ha ${ }^{-1}$ and a row width of $2.2 \mathrm{~m}$. The randomized block design with three replications is represented in Fig. 2 (first replication). Each cover crop was seeded on 3 inter-rows $(2.2 \mathrm{~m} \times 3 \mathrm{~m}=6.6 \mathrm{~m})$ for a total of 21 inter-rows ( 3 inter-rows $\times 7$ 7 treatments $=21$ inter-rows) by replication. Cover crops were also seeded in the experimental site one year before the study period. Cover crops were chosen following certain criterions: plant adaptability, seed price and availability, speed emergence and soil cover. Soil and plant samples were collected in the middle inter-row. Rows were $140 \mathrm{~m}$ long with a slope of $15.9 \%$. The inter-rows were managed with conventional tillage (CT) and alternative tillage using cover crops: (1) Vicia faba (VF); (2) V. faba and Vicia sativa (VV); (3) Trifolium subterraneum, Festuca rubra, and Lolium perenne (TFL); (4)T. subterraneum, F. rubra, and Festuca ovina (TFF); (5) Triticum durum (T); and (6) T. durum and V. sativa (TV). For CT, 3-4 ploughings per year, $0.15 \mathrm{~m}$ deep, were started after the first rain in September or October to bury weeds and aerate the topsoil. TFL and TFF were permanent meadows with a vegetative stasis during the summer period. Cover crops were seeded in October using special sod seeding equipment (1.60 $\mathrm{m}$ wide) and biomass was buried during the month

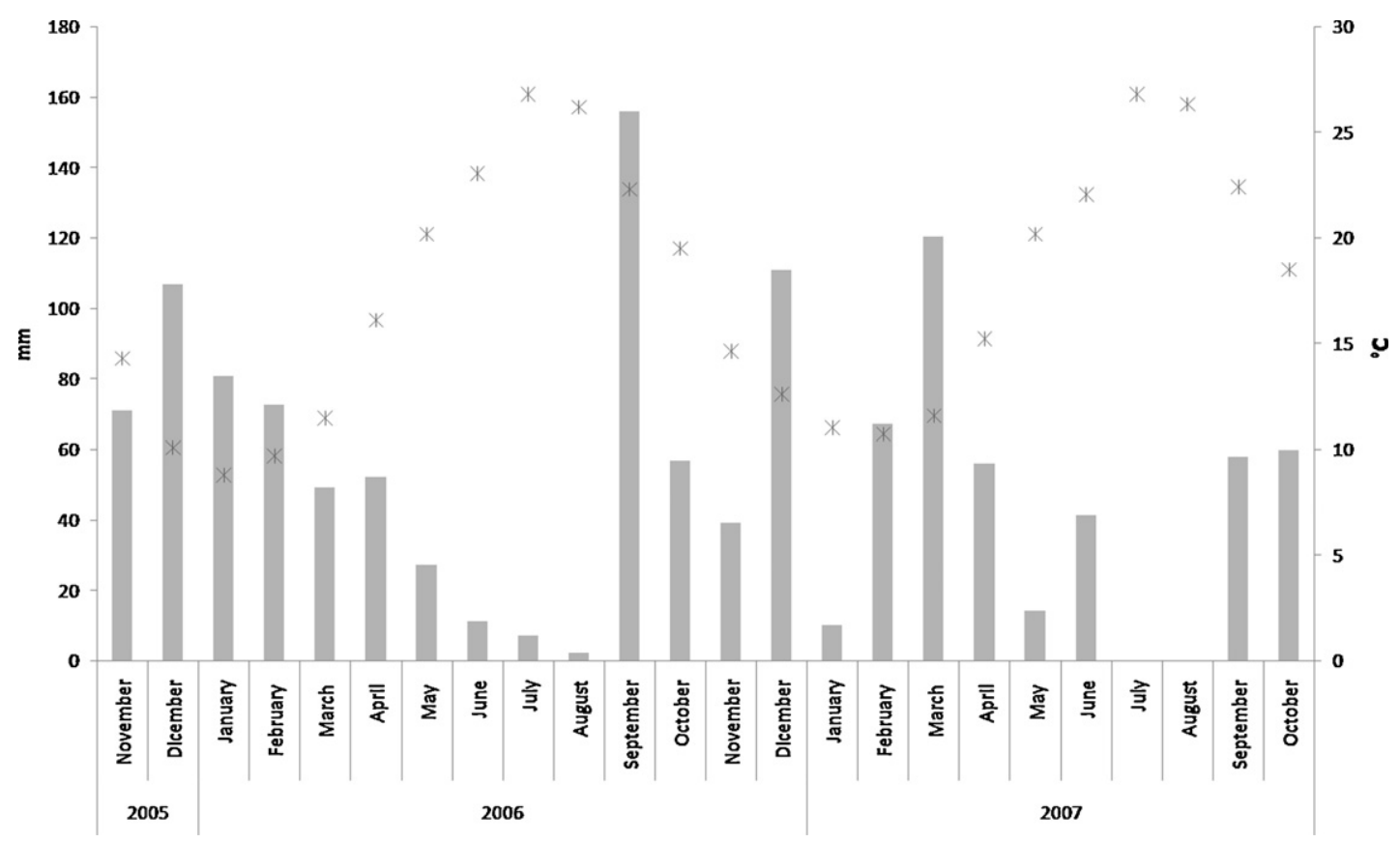

Fig. 1. Montlhy rainfall and mean temperature from November 2005 to October 2007. 


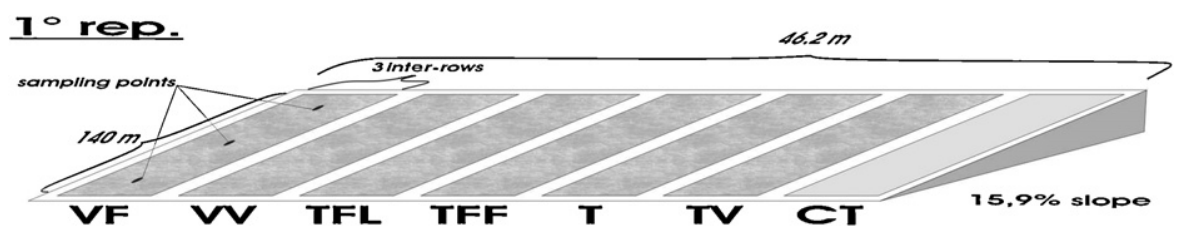

Fig. 2. Experimental set-up in the vineyards.

of April by rotary tillage except for TFL and TFF which were allowed to establish permanent vegetation.

\subsection{Soil loss quantification}

In order to determine erosion rates in the vineyard managed by traditional farming, poles were used as erosion markers. In the studied vineyard an espalier structure was built using poles $220 \mathrm{~cm}$ in height. During plantation of vines $\left(t_{\mathrm{i}}\right)$, poles were carefully planted using a machine for pile driving to a standard depth of $60 \mathrm{~cm}$ and an intra-row distance of $5.0 \mathrm{~m}$ (Fig. 3). After 9 years $\left(t_{\mathrm{f}}\right)$ pole overground height $\left(h_{\mathrm{f}}\right)$ was measured for each pole of three rows in the control plot, checking pole verticality before measuring. $h_{\mathrm{f}}$ for each pole is the average of 15 measurements; measurement points were taken each $15 \mathrm{~cm}$ in the inter-row between two poles.

For each pole, the difference $(h)$ between $h_{\mathrm{f}}$ and $h_{\mathrm{i}}$ (over-ground height at $t_{\mathrm{i}}$ ) indicated the topographical change since the pole installation which is the soil erosion or deposition. With $h$-values interpolated using a polynomial curve, the soil erosion volume was equal to the polynomial area multiplied by the plot length. Soil bulk density was measured at $10 \mathrm{~cm}$ depth in three sampling points along the slop using the core method (Blake and Hartge, 1986) in order to transform the calculated volume into weight $\left(\mathrm{Mg} \mathrm{ha}^{-1}\right)$. Due to soil redistribution, patches of eroded and accumulated material were found. An area index was calculated between two consecutive poles using the equation below:

$I=\frac{h_{\mathrm{f}, 1}-h_{\mathrm{f}, 1+n}}{h_{\mathrm{i}}}$

where $h_{\mathrm{f}, 1}$ is the over-ground height of a pole at the present time and $h_{\mathrm{f}, 1+n}$ is the height of the next pole at lower elevation. The erosion index is $>0$ in a soil erosion area, $<0$ in a soil accumulation area and $=0$ when soil loss $=$ soil sedimentation.

To monitor water and sediment yield in a short period, a $1 \mathrm{~m}$ wide Gerlach trap (Gerlach, 1967) with a 40 L deposit was installed at each treatment site on the vineyard inter-row. The vineyard rows and a bank on the top of the plot were used as a border. Runoff and suspended sediment concentration were measured after each significant rainfall event determined using a rain gauge $(0.2 \mathrm{~mm}$ accuracy) from November 2005 to October 2007. Sediments were weighed after desiccation. The soil erosion rates were calculated from the runoff, the sediment concentration and the plot area.

\subsection{Soil and plant analysis}

Soil sampling was done at $0-20 \mathrm{~cm}$ depth for each plot. Samples were air dried and passed through a $2 \mathrm{~mm}$ sieve and soil organic carbon and texture were determined. These results were used to calculate the $\mathrm{K}$ factor using USLE. Dry biomass weight was determined on three $1 \mathrm{~m}^{2}$ square area sub samples for each cover crop before green manure.

\subsection{C-factor estimation}

The USLE scheme was applied to estimate $C$-factor for each cover crop group:

$C=\frac{2242 \times A}{R \times K \times L S \times P}$

where $A$ is soil loss $\left(\mathrm{Mg} \mathrm{ha}^{-1}\right), \quad R$ is rainfall factor (MJ $\mathrm{mm} \mathrm{ha}^{-1} \mathrm{~h}^{-1}$ year $^{-1}$ ), $K$ is the soil erodibility factor ( $\mathrm{Mg}$ ha $\mathrm{h} \mathrm{MJ}^{-1} \mathrm{ha}^{-1} \mathrm{~mm}^{-1}$ ), $L S$ is the topographic factor, and $P$ is the support practice. $R$ factor was calculated using the Wischmeier and Smith equation; it is the average yearly sum of the products of the Kinetic energy $\left(E=0.119+0.0873 \times \log 10 I_{30}\right)$ of each storm times and the maximum intensity of the storm recorded in $30 \mathrm{~min} . K$ factor was determined from the following equation (Wischmeier and Smith, 1978):

$K=\frac{2.1 \times 10^{-4} \times M^{1,14} \times(12-O M)+3.25 \times(S S-2)+2.5 \times(P P-3)}{100}$

where $M=(\%$ silt $+\%$ very fine sand $) \times(100-\%$ clay $)$; $O M$ is organic matter (\%); SS is soil structure code used in soil classification (1-4); PP is the profile-permeability class (1-6).

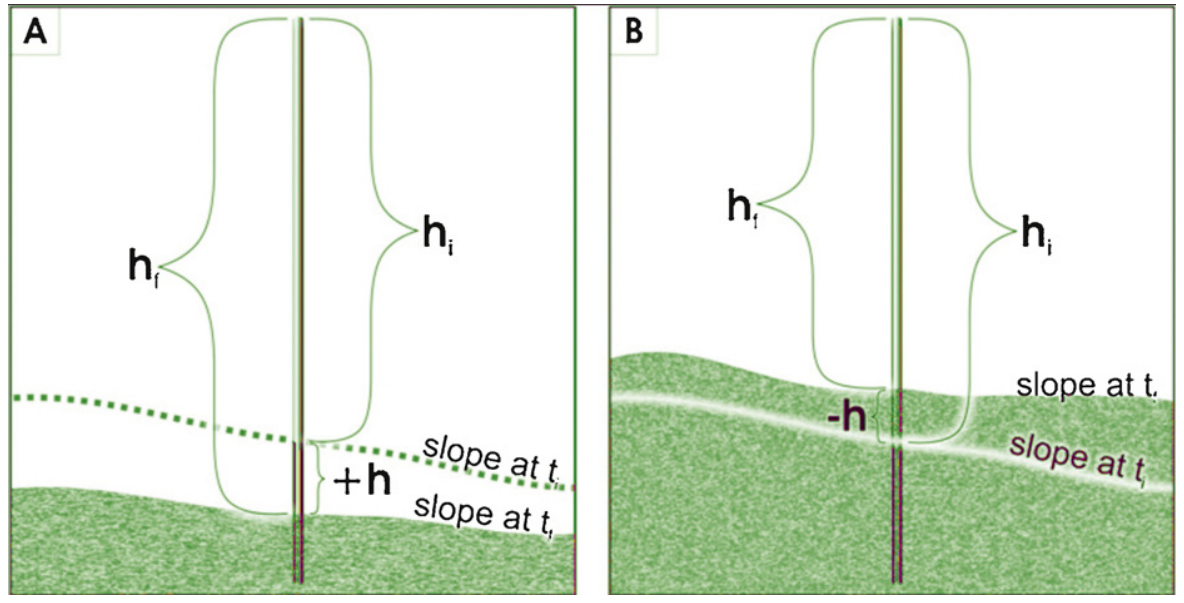

Fig. 3. Soil erosion in a longer period: (A) soil erosion $(+h)$; (B) soil erosion deposition $(-h)$. 


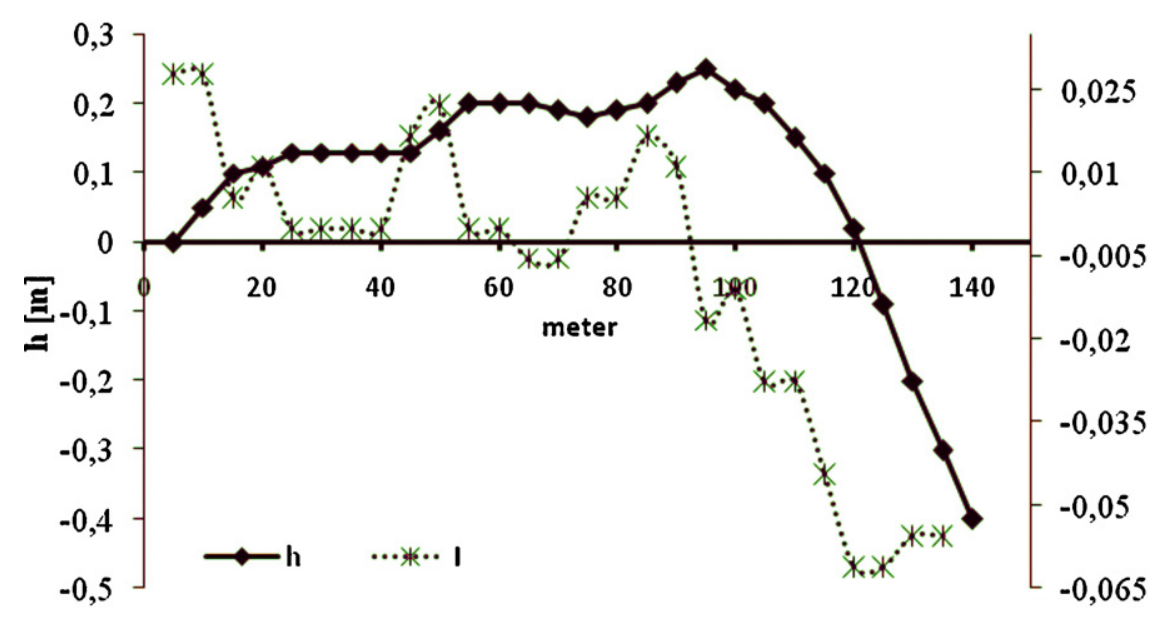

Fig. 4. The $h$ values and $I$ index in the control plot along the slope.

LS factor was calculated with the following equation (McCool et al., 1989):

$L S=\left(\frac{\lambda}{22.13}\right)^{m} \times(16.8 \times \sin \alpha-0.5)$

where $\lambda$ is slope length of the morphological area, $\alpha$ is the slope angle and

$m=\frac{f}{(1+f)}$

and

$f=\frac{\sin \alpha}{0.0896 \times\left(3 \sin ^{0,8} \alpha+0.56\right)}$

The $P$ factor was set equal to 1 given that no support practice control was applied.

\subsection{Statistical analyses}

Data analysis was conducted using the SAS statistical package (SAS Institute, 2002). After the normal distribution of the data was checked, analysis of the variance in the data was conducted according to the experimental design. A repeated measure analysis on the fifteen erosion events was carried out to stress different behavior of the cover crops over time.

\section{Results}

\subsection{Nine years soil erosion rates}

The differences between pole heights at $t_{\mathrm{i}}$ and $t_{\mathrm{f}}$ are illustrated in Fig. 4. These data show the topographical changes in the vineyard plot managed with CT during 9 years. $h$ value was not constant along the slope, but rather ranged from 0.25 to $-0.40 \mathrm{~m}$. The $h$ value was $0.11 \mathrm{~m}$ in the upper slope part and $0.20 \mathrm{~m}$ in the middle of the slope part ( $50 \mathrm{~cm}$ from the top of the slop). $I$ index varied from -0.06 (deposition area) to +0.02 (erosion area). As shown in Fig. 5 , the $I$ index is $<0$ at the lower part of the row. But some patches within the slope where found with a positive value due to sediment deposition.

The total erosion volume during the 9 years was calculated as the difference between the erosion volume and the deposition volume for the whole plot. The mean erosion rate was 102.2 $\mathrm{Mg} \mathrm{ha}^{-1}$ year $^{-1}$ The erosion rates ranged from 86 to $118.5 \mathrm{Mg} \mathrm{ha}^{-1}$ year $^{-1}$. The higher erosion rates were found on the upper slope part and on the middle part, and the deposit sites on the lower position.

\subsection{Biomass characteristics}

The average biomass production over a 2 year period is presented in Table 1. TV yielded more biomass than the other cover crops. Dry matter ranged from $4.67 \pm 2.64 \mathrm{Mg} \mathrm{ha}^{-1}$ for VF treatment to $12.40 \pm 4.10 \mathrm{Mg} \mathrm{ha}^{-1}$ for TV treatment. The average biomass production in the first year was lower than in the second year.

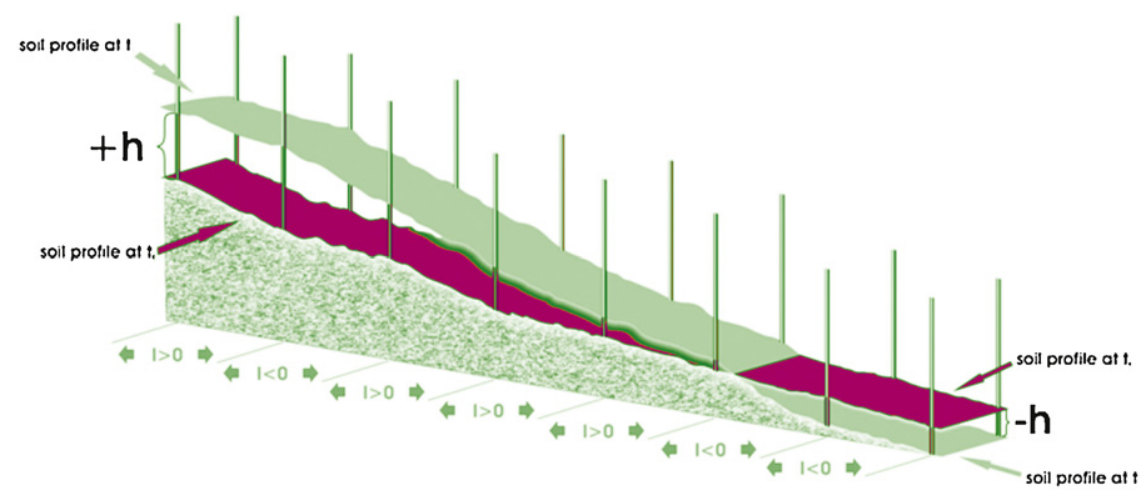

Fig. 5. Tridimensional scheme for soil erosion and deposition volumes over 9 years. 
Table 1

Main characteristics of the six cover crops tested.

\begin{tabular}{|c|c|c|c|c|c|}
\hline Cover crop treatments & Abbreviation & $\begin{array}{l}\text { Seeding rate } \\
\left(\mathrm{kg} \mathrm{ha}^{-1}\right)\end{array}$ & $\begin{array}{l}\text { Emergence } \\
\text { (days after seeding) }\end{array}$ & $\begin{array}{l}\text { 50\% covering } \\
\text { (days after seeding) }\end{array}$ & $\begin{array}{l}\text { Dry weight } \\
\left(\mathrm{Mg} \mathrm{ha}^{-1}\right)\end{array}$ \\
\hline Vicia faba & VF & 250 & 21 & 90 & $4.67 \pm 2.6$ \\
\hline $\begin{array}{l}\text { V. faba } \\
\text { Vicia sativa }\end{array}$ & VV & $\begin{array}{r}125 \\
60\end{array}$ & 20 & 85 & $7.13 \pm 4.6$ \\
\hline $\begin{array}{l}\text { Trifolium subterraneum } \\
\text { Festuca rubra } \\
\text { Lolium perenne }\end{array}$ & TFL & $\begin{array}{r}10 \\
8 \\
4\end{array}$ & 14 & 70 & $9.49 \pm 2.5$ \\
\hline $\begin{array}{l}\text { T. subterraneum } \\
\text { F. rubra } \\
\text { Festuca ovina }\end{array}$ & TFF & $\begin{array}{r}10 \\
8 \\
4\end{array}$ & 14 & 70 & $6.32 \pm 1.2$ \\
\hline Triticum durum & $\mathrm{T}$ & 200 & 15 & 60 & $11.2 \pm 3.4$ \\
\hline $\begin{array}{l}\text { T. durum } \\
\text { V. sativa }\end{array}$ & TV & $\begin{array}{r}100 \\
60\end{array}$ & 20 & 65 & $12.4 \pm 4.1$ \\
\hline
\end{tabular}

Table 2

Soil erosion sediments during 15 events of observation $\left(\mathrm{Mg} \mathrm{ha}^{-1}\right)$.

\begin{tabular}{|c|c|c|c|c|c|c|c|c|c|c|c|c|c|c|c|}
\hline & $\begin{array}{l}10 / 11 / \\
05\end{array}$ & $\begin{array}{l}18 / 11 / \\
05\end{array}$ & $\begin{array}{l}22 / 11 / \\
05\end{array}$ & $\begin{array}{l}28 / 11 / \\
05\end{array}$ & $\begin{array}{l}05 / 12 / \\
05\end{array}$ & $\begin{array}{l}07 / 12 / \\
05\end{array}$ & $\begin{array}{l}16 / 12 / \\
05\end{array}$ & $\begin{array}{l}04 / 01 / \\
06\end{array}$ & $\begin{array}{l}03 / 02 / \\
06\end{array}$ & $\begin{array}{l}02 / 03 / \\
2006\end{array}$ & $\begin{array}{l}14 / 03 / \\
06\end{array}$ & $\begin{array}{l}12 / 02 / \\
07\end{array}$ & $\begin{array}{l}12 / 03 / \\
07\end{array}$ & $\begin{array}{l}27 / 03 / \\
07\end{array}$ & $\begin{array}{l}10 / 04 / \\
07\end{array}$ \\
\hline VF & 9.47 & 4.39 & 4.48 & 1.52 & 3.35 & 3.65 & 5.60 & 4.94 & 3.80 & 10.26 & 9.25 & 1.50 & 2.97 & 1.64 & 5.65 \\
\hline VV & 2.58 & 1.94 & 3.12 & 0.37 & 0.55 & 0.68 & 1.20 & 4.48 & 2.48 & 2.07 & 1.15 & 2.84 & 0.00 & 2.35 & 4.30 \\
\hline TFL & 5.33 & 1.17 & 2.64 & 1.93 & 0.48 & 1.86 & 3.45 & 3.56 & 3.11 & 8.94 & 8.02 & 0.07 & 0.01 & 0.00 & 0.02 \\
\hline TFF & 2.21 & 0.38 & 2.43 & 0.37 & 0.56 & 0.33 & 3.72 & 2.30 & 1.48 & 9.26 & 4.82 & 0.13 & 0.15 & 0.03 & 0.28 \\
\hline $\mathrm{T}$ & 3.89 & 4.20 & 5.12 & 0.41 & 0.38 & 1.64 & 5.90 & 6.51 & 6.76 & 7.97 & 6.93 & 0.15 & 0.03 & 0.61 & 2.36 \\
\hline TV & 3.86 & 1.79 & 2.32 & 0.39 & 0.84 & 1.00 & 2.77 & 5.23 & 4.07 & 5.66 & 2.42 & 0.51 & 0.31 & 1.33 & 3.82 \\
\hline CT & 4.60 & 18.62 & 5.38 & 0.40 & 2.49 & 3.31 & 10.01 & 6.63 & 12.21 & 15.80 & 9.25 & 9.57 & 4.08 & 4.86 & 12.89 \\
\hline
\end{tabular}

Biomass weight in the first year was $30 \%$ less for all cover crops except for VF and VV treatments, which showed 65\% and 68\% greater biomass for the first and the second year, respectively. The most rapidly time of emergence was recorded for TFL and TFF, followed by T which covered $50 \%$ of soil before than other cover crops (see Table 1 ).

\subsection{Soil and water losses}

The main erosion sediment amount in each soil management tested was recorded in autumn and winter period, which are the rainiest seasons. Summer was always dry and no runoff was measured. Eleven erosion events were recorded during the first year while in the second there were 9 runoff events but only four of them contributed with sediment yield (Table 2). The average soil erosion rates varied from 0.77 to $8.57 \mathrm{Mg} \mathrm{ha}^{-1}$. After two years (from November 2005 to October 2007), soil erosion rates were significantly reduced by cover crops relative to CT. Repeated measures (species vs. time) emphasized a highly significant interaction due to the characteristics of the different species (emergence, soil cover ability and total biomass yield, see Table 2 ). The TFF cover crop group decreased the soil losses by $76 \%$ compared to CT. The least effective cover crop group was VF with $39.6 \%$ reduction. Cover crops with VV, TFL, TD, and TV decreased soil erosion by $74.94 \%, 66.2 \%, 56 \%$ and $69.8 \%$, respectively,

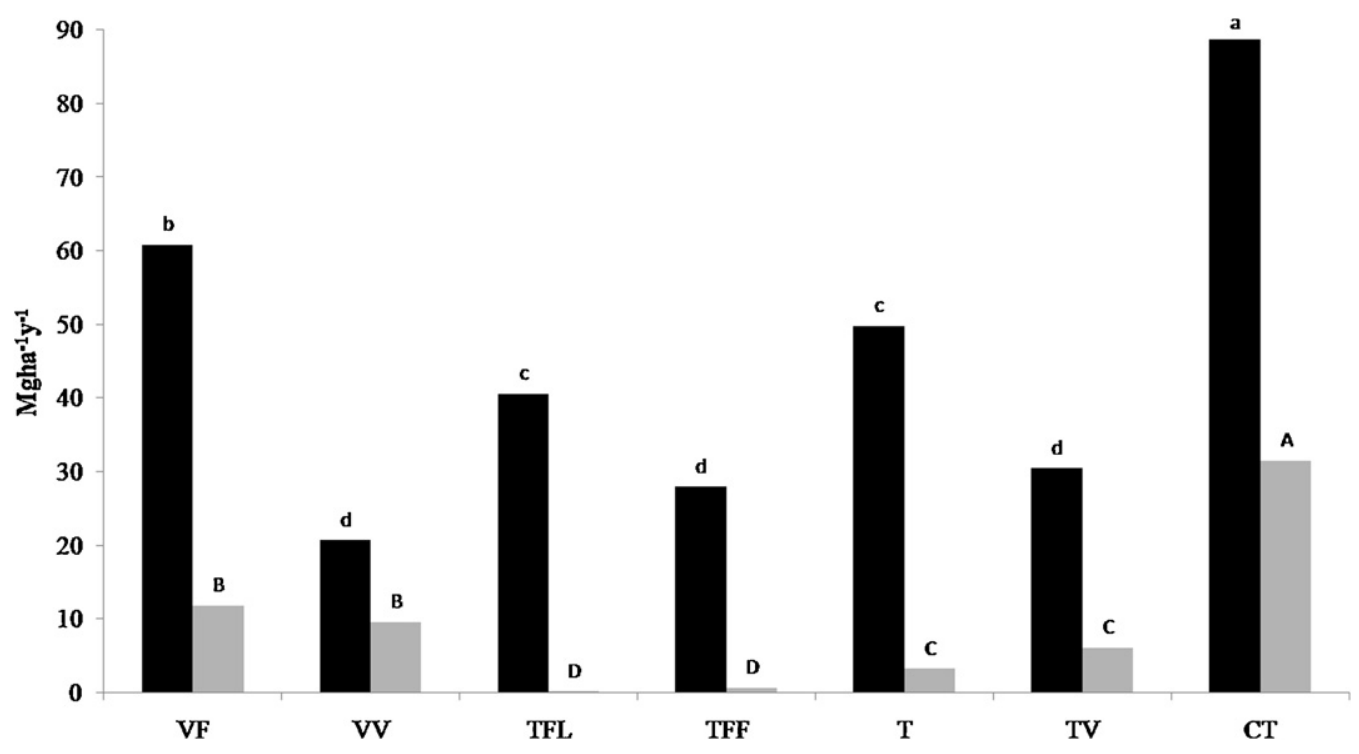

Fig. 6. Cumulative soil loss from November 2005 to October 2006 (black histograms) and from November 2006 to October 2007 (grey histograms). 


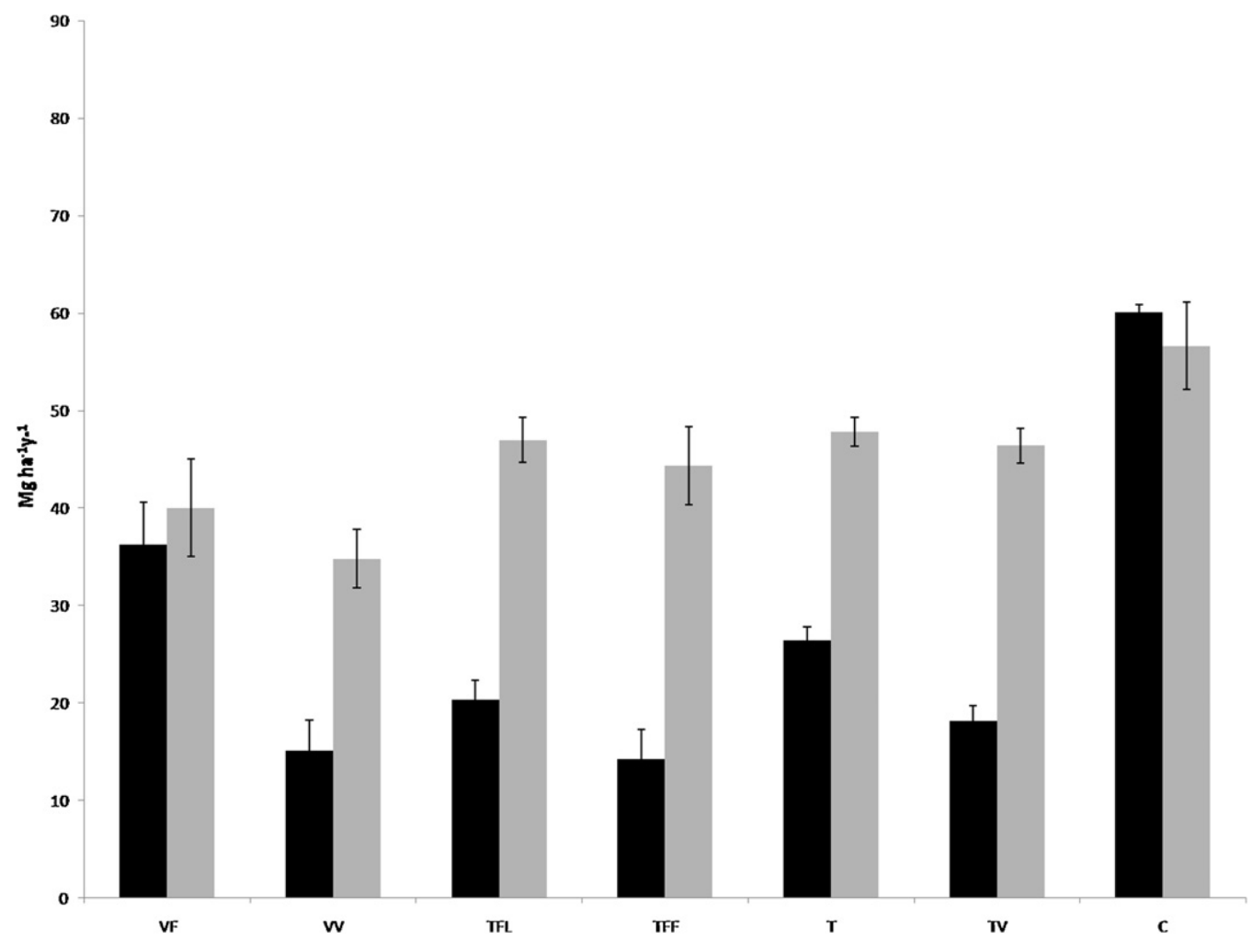

Fig. 7. Average of two years of water runoff (grey columns) and sediment erosion (black columns).

compared to CT. The soil loss rates during the first year were higher than during the second year. From November 2005 to October 2006 (first year), it was observed that erosion ranged from $20.61 \mathrm{Mg} \mathrm{ha}^{-1}$ in VV cover crop to $88.71 \mathrm{Mg} \mathrm{ha}^{-1}$ in the control plot (Fig. 6). During the second year soil erosion ranged from $0.10 \mathrm{Mg} \mathrm{ha}^{-1}$ in TFL plot to $31.4 \mathrm{Mg} \mathrm{ha}^{-1}$ in CT (Fig. 6). For runoff, significantly higher values for CT were recorded than for all other cover crops. From November 2006 to October 2007 (second year), cumulative runoff ranged from $56.63 \mathrm{~mm}$ for CT to $34.79 \mathrm{~mm}$ in VV cover crop management (Fig. 7). Values of water runoff and especially of soil sediment deposition were quite different in the two years of study, depending on erosivity of rainfall. Soil erosion was higher in the first year; in particular, in autumn 2005 due to a short and intense storm $(12.2 \mathrm{~mm} / 10 \mathrm{~min})$ resulted in severe runoff and sediment deposition in the bottom rows.

\subsection{C-factor}

$C$-factor values for each of the six different cover crop groups was calculated in order to compare the effectiveness of different land covers on erosion control (Fig. 8). For all six cover crops the

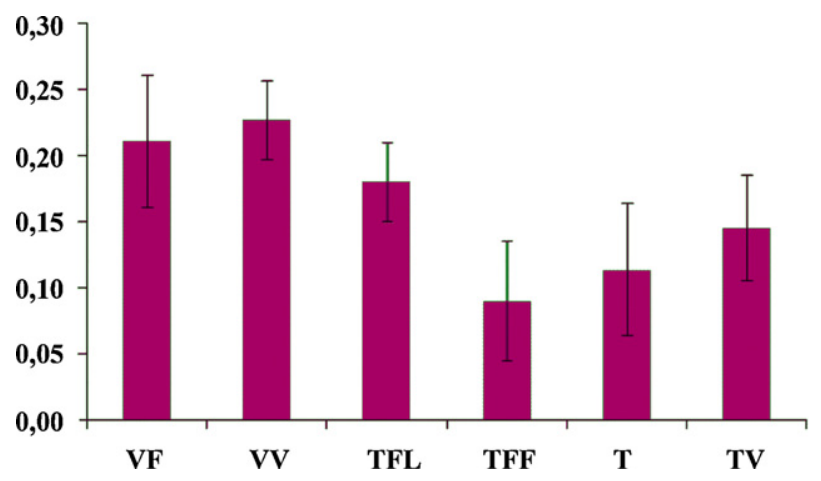

Fig. 8. USLE cover management $C$-factor for the six cover crops tested. mean $C$-factor value was 0.18 with a standard deviation of 0.06 . In two years the average of values ranged from 0.09 to 0.23 . The treatment most effective for reducing sediment loss was TFF with a $C$ factor value of $0.09 \pm 0.045$, followed by T treatment $(0.11 \pm 0.05)$. The highest $C$-factor was obtained with leguminous cover crops VV and VF due to their poor effectiveness to cover tickly soil surface. $C$-factor value of 0.23 and 0.21 were respectively recorded in VV and VF treatments. No significant differences were found between the first and the second year of observations, nevertheless cumulative rainfall was different. In two years of observations $C$-factor ranged from 0.18 to 0.29 for $V F$, from 0.17 to 0.23 for TFL, from 0.06 to 0.015 for TFF and from 0.12 to 0.20 for TV treatment. The lowest and the highest range were recorded in VV (0.22-0.28) and T cover crop treatment (0.07-0.019), respectively.

\section{Discussion}

Sicilian vineyards are prone to erosion risks. In a southwestern Sicilian vineyard managed with conventional tillage for 9 years, we used an innovative pole method to measure higher erosion rates in a longer period than those obtained using the Gerlach method. The pole method allows calculation of the absolute erosion and/or sedimentation along vineyard rows. In fact, the $h$ values shown in Fig. 6, define separate erosion and deposition areas each $5 \mathrm{~m}$ along the row on the slope row. Other commonly used methods to measure soil erosion rate include the well known universal soil loss equation (USLE; Wischmeier and Smith, 1978) and the revised USLE (RUSLE; Renard et al., 1997). In studies where soil erosion estimates using USLE or similar models were compared directly with field observations (Azpizua, 2003; De la Rosa et al., 2005), large errors exist. Both USLE and RUSLE model sets are derived from an extensive database but their general parameters contain uncertainty when applied to specific areas (Wang et al., 2001). These parameters depend on other variables and change over space and time. Other methods to estimate soil erosion rates involve rare earth element oxide (REO) tracers using (Stevens and Quinton, 2008) or radioisotope tracing using cesium-137 (Quine and Walling, 1991; Ritchie 
et al., 2005), lead-201 (Walling and He, 1999), or beryllium-7 (Matisoff et al., 2002). Isotopic methods are expensive and require specialists. Biomarkers such as tree ring characteristics (Carrara and Carroll, 1979; Gartener, 2007) and exposed tree roots below the tree canopy (Biot, 1990; Schnabel, 1994; Gärtner et al., 2001; Bodoque et al., 2002; Gärtner, 2006) are also used to measure soil erosion rates. In vineyards, Casalí et al. (2009) and Vanwalleghem et al. (2010) used the graft point as botanical benchmarks. Such biomarkers are useful for long-term erosion quantification but are prone to errors due simply to the natural variability of plants. For example, when using exposed tree roots as a biomarker, large error is often introduced by estimating the original root depth, a metric of high variability in most plants (Schnabel, 1994).

Our simple methods provide to obtain data on soil erosion in a longer period. Additionally it is an inexpensive method, does not hamper soil management practices and therefore could be applied to large scale.

In regard to higher soil erosion rates measured under soil conventional tillage management, some soil conservation system needs to be applied. In Sicilian vineyards, an alternative soil management system to conventional tillage involves the planting of cover crops. By means of a plot approach, it was demonstrated that sowing the appropriate cover crops can reduce soil erosion by $68 \%$ compared with conventional tillage. This result is not very different from those reported in other studies in the Mediterranean. In Spain for example, Marques et al. (2009) found that tilled rows lost an average of $1.059 \mathrm{~g} \mathrm{~m}^{-2}$ year $^{-1}$ compared to 62 and $70 \mathrm{~g} \mathrm{~m}^{-2}$ year $^{-1}$ lost in rows planted with cover crops of Secale sp. and Brachypodium sp., respectively. Similarly, the results confirm that cover crops are a good soil conservation practice compared to traditional tillage and the magnitude of erosion volume reduction depends on the cover crop species. In this study, the lowest soil losses were found with TFF in both years, followed by TD, as highlighted by USLE cover management $C$-factors. The poor performance of $\mathrm{VF}$ alone in reducing erosion is due to its relatively low biomass production. Furthermore, established leguminous plants protect the soil from raindrop impacts in late winter and spring. Without any cover crops, soil is bare during the high-intensity rainfall in autumn. Permanent meadows are efficient for erosion control because of their characteristic of dense growths and fibrous root systems. Soil managed with TFF and TLF cover crops allow a continuous cover during the year. This is due to the fact that during the summer season soil is covered by the dry meadow biomass until autumn when the meadow seeds germinate and establish rapidly after the autumn rains. This constant ground cover during the year protects the vineyard soil from erosion.

\section{Conclusions}

An alternative soil management system based on planting of the appropriate cover crops between the rows of a vineyard effectively traps water and decreases soil erosion. In this study we tested six different cover crop groups applicable to the Mediterranean region and determined that a $T$. subterraneum, F. rubra, and $L$. perenne or T. subterraneum, F. rubra, and F. ovina provide the most effective ground cover for erosion control. Additionally, this study provides an innovative tool for measuring the annual erosion rate in vineyards. Determination of erosion in a longer period using pole heights is an easy and inexpensive method that can be used by grape growers to monitor soil erosion and by government institutions to establish future policies on land degradation.

\section{Acknowledgments}

The authors gratefully acknowledge Salvatore Sacco for field assistance and Feudo Arancio Winery for giving us access to its fields. This project was financially supported by Assessossorato Agricoltura - Regione Sicilia.

\section{References}

Assizes, R., 2003. Erosion assessment and conservation measures in sloping and mountainous olive production systems in Andalucía. OLIVERO student report series no. 2.

Biot, Y., 1990. The use of tree mounds as benchmarks of previous land surfaces in a semiarid tree savanna, Botswana. In: Thornes, J.B. (Ed.), Vegetation and Erosion. John Wiley \& Sons, Chichester, pp. 437-450.

Blake, G.R., Hartge, K.H., 1986. Bulk density. In: Klute, A. (Ed.), Methods of Soil Analysis. Part 1. Agronomy Monograph, 2nd ed., vol. 9. American Society of Agronomy, Madison, WI, pp. 363-375.

Boardman, J., Poesen, J., 2006. Soil Erosion in Europe. Wiley, Chichester.

Bodoque, J.M., Díez, A., Martín-Duque, J., Gómez, A., Godfrey, J., Pedraza, J., Carrasco, R.M., Sanz, M.A., 2002. Determinación de tasas de erosión utilizando métodos dendrocronologógicos en raíces expuestas, Dos ejemplos en la vertiente septentrional de la Sierra de Guadarrama, Estudios recientes (2000-2002). In: Geomorfología-Patrimonio, montaña y dinámica Territorial, Dpto. GeografíaUVA, Valladolid, doi:10.1016/j.catena.2009.02.015, pp. 167-182.

Bouchet, E., Rubio, J.L., Poesen, J., 1999. Modified topsoil islands within patchy Mediterranean vegetation in S.E. Spain. Catena 38, 23-44, doi:10.1016/S03418162(99)00056-9.

Cantón, Y., Solé-Benet, A., Asensio, C., Chamizo, S., Puigdefábregas, J., 2009. Aggregate stability in range sandy loam soils. Relationships with runoff and erosion. Catena 77, 192-199, doi:10.1016/j.catena.2009.03.001

Carrara, P.E., Carroll, T.R., 1979. The determination of erosion rates from exposed tree roots in the Piceance Basin, Colorado. Earth Surface Processes 4, 307-317, doi:10.1002/esp.3290040402.

Casalí, J., Giménez, R., De Santisteban, L., Álvarez-Mozos, J., Mena, J., Del Valle de Lersundi, J., 2009. Determination of long-term erosion rates in vineyards of Navarre (Spain) using botanical benchmarks. Catena 12-19 , doi:10.1016/ j.catena.2009.02.015

Cerdà, A., 1996. Soil aggregate stability in three mediterranean environments. Soil Technology 9, 129-133.

Cerdà, A., 1998. The influence of geomorphological position and vegetation cover on the erosional and hydrological processes on a Mediterranean hillslope. Hydrological Processes 12, 661-671.

Cerdà, A., Imeson, A.C., Poesen, J., 2007. Soil water erosion in rural areas. Catena (Special issue) 71, 191-252.

Cerdà, A., Flanagan, D.C., le Bissonnais, Y., Boardman, J., 2009. Soil erosion and agriculture. Soil and Tillage Research 107-108, doi:10.1016/j.still.2009.10.006.

Cerdà, A., Hooke, J., Romero-Diaz, A., Montanarella, L., Lavee, H., 2010. Soil erosion on mediterranean type-ecosystems. Land degradation and development. Editors, doi:10.1002/ldr.968.

Day, P.R., 1965. Particle fractionation and particle-size analysis. In: Black, C.A. (Ed.), Methods of Soil Analysis, Part 1. American Society of Agronomy, Inc., Madison, WI, pp. 545-567.

De la Rosa, D., Diaz-Pereira, E., Mayol, F., Czyz, E.A., Dexter, A.R., Dumitru, E., Enache, R., Fleige, H., Horn, R., Rajkay, K., Simota, C., 2005. SIDASS project. Part 2. Soil erosion as a function of soil type and agricultural management in a Sevilla olive area, southern Spain. Soil and Tillage Research 82, 19-28, doi:10.1016/ j.still.2005.01.004

De Santisteban, L.M., Casalí, J., López, J.J., 2006. Assessing soil erosion rates in cultivated areas of Navarre (Spain). Earth Surface Processes and Landforms 31 487-506, doi:10.1002/esp.1281.

Durán-Zuazo, V.H., Rodríguez-Plequezuelo, C.R., 2008. Soil-erosion and runoff prevention by plants cover. A review. Agronomy for Sustainable Development 28, 65-86, doi:10.1016/j.catena.2008.12.005.

Folorunso, O.A., Rolston, D.E., Prichard, T., Louie, D.T., 1992. Soil surface strength and infiltration rate as affected by winter cover crops. Soil Technology 5, 189-197, doi:10.1016/0933-3630(92)90021-R.

García-Orenes, F., Guerrero, C., Mataix-Solera, J., Navarro-Pedreño, J., Gómez, I. Mataix-Beneyto, J., 2005. Factors controlling the aggregate stability and bulk density in two different degraded soils amended with biosolids. Soil and Tillage Research 82, 65-76.

García-Orenes, F., Cerdà, A., Mataix-Solera, J., Guerrero, C., Bodí, M.B., Arcenegui, V., Zornoza, R., Sempere, J.G., 2009. Effects of agricultural management on surface soil properties and soil-water losses in eastern Spain. Soil and Tillage Research 106 (1), 117-123, doi:10.1016/j.still.2009.06.002.

García-Orenes, F., Guerrero, C., Roldán, A., Mataix-Solera, J., Cerdà, A., Campoy, M., Zornoza, R., Bárcenas, G., Caravaca, F., 2010. Soil microbial biomass and activity under different agricultural management systems in a semiarid Mediterranean agroecosystem. Soil and Tillage Research 109, 110-115, doi:10.1016 j.still.2010.05.005.

García-Ruiz, J.M., 2010. The effects of land uses on soil erosion in Spain: a review. Catena 81,1-11, doi:10.1016/j.catena.2010.01.001.

Gärtner, H., Schweingruber, F.H., Dikau, R., 2001. Determination of erosion rates by analyzing structural changes in the growth pattern of exposed roots. Dendrochronologia 19 (1), 81-91, doi:10.1016/j.geomorph.2006.09.001.

Gärtner, H., 2006. Tree roots-methodological review and new development in dating and quantifying erosive processes. Geomorphology 86 (2-3), 243-251 doi:10.1016/j.geomorph.2006.09.001. 
Gerlach, T., 1967. Hillslope troughs for measuring sediment movement. Rev. Geomorph. Dyn. 4, 173-175.

Gristina, L., Bagarello, V., Ferro, V., Poma, I., 2006. Cover and management factor for Sicilian vineyard systems. In: 14th International Soil conservation Organization Conference-Water Management and Soil Conservation in Semi-arid Environments, 14-19 May 2006, Marrakech, Marocco (ISCO2006), pp. 1-4.

Gristina, L., Ferrotti, F., Poma, I., Saladino, S., Barbagallo, M.G., Costanza, P., 2005. Sustainable Use and Management of Soils - Arid and Semiarid Regions. In: Faz Cano, A., Ortiz, R., Mermut, A.R. (Eds.), Advances in GeoEcology, 36. Catena Verlag, pp. 103-112.

Gulick, S.H., Grimes, D.W., Munk, D.S., Goldhamer, D.A., 1994. Cover-crop-enhanced water infiltration of a slowly permeable fine sandy loam. Soil Science Society of America Journal 58, 1539-1546, doi:10.2136/sssaj2003.0747.

Kosmas, C., Danalatos, N., Cammeraat, L.H., Chabart, M., Diamantopoulos, J., Farand, R., Gutiérrez, L., Jacob, A., Marques, H., Martínez-Fernández, J., Mizara, A. Moutakas, N., Nicolau, J.M., Oliveros, C., Pinna, G., Puddu, R., Puigdefábregas, J., Roxo, M., Simao, A., Stamou, G., Tomasi, N., Usai, D., Vacca, A., 1997. The effect of land use on runoff and soil erosion rates under Mediterranean conditions. Catena 29, 45-59, doi:10.1016/S0341-8162(96)00062-8.

Lasanta, T., Sobrón, I., 1988. Influencia de las prácticas de laboreo en la evolución hidromorfológica de suelos cultivados con viñedo. Cuadernos de Investigación. Geográfica 14, 81-97, doi:10.1016/j.still.2006.05.013.

Le Bissonnais, Y., Arrouays, D., 1997. Aggregate stability and assessment of soil crustability and erodibility. II. Application to humic loamy soils with various organic carbon contents. European Journal of Soil Science 48, 39-48, doi:10.1111/j.1365-2389.1997.tb00183.

Marques, M.J., Garcia-munoz, S., Munoz-organero, G., Bienes, R., 2009. Soil conservation beneath grass cover in hillside vineyards under mediterranean climatic conditions (Madrid, Spain). Land Degradation and Development 20, 1-10, doi:10.1002/ldr.915.

Mataix-Solera, J., Gómez, I., Navarro-Pedreño, J., Guerrero, C., Moral, R., 2002. Soil organic matter and aggregates affected by wildfire in a Pinus halepensis forest in Mediterranean environment. International Journal of Wildland Fire 11, 107114.

Matisoff, G., Bonniwell, E.C., Whiting, P.J., 2002. Soil erosion and sediment sources in an Ohio watershed using beryllium-7, cesium-137, and lead-210. Journal of Environmental Quality 31, 54-61, doi:10.2134/jeq2002.0054.

McCool, D.K, Foster, G.R., Mutchler, C.K., Meyer, L.D., 1989. Revised slope length factor for the universal soil loss equation. Transactions of the ASAE 32 (5), 1571-1576, doi:10.2489/jswc.63.3.105.

Oldeman, L.R., 1994. The global extent of land degradation. In: Greenland, D.J., Szabolcs, I. (Eds.), Land Resilience and Sustainable Land Use. Wallingford, UK, pp. 99-118, doi:10.1098/rstb.2010.0127.

Quine, T.A., Walling, D.E., 1991. Rates of soil erosion on arable fields in Britain: quantitative data from caesium-137 measurements. Soil Use and Management 7, 169-176, doi:10.1111/j.1475-2743.1991.tb00870.x.

Quinton, J.N., Catt, J.A., 2004. The effects of minimal tillage and contour cultivation on surface runoff, soil loss and crop yield in the long-term Woburn Erosion
Reference Experiment on sandy soil at Woburn, England. Soil Use and Management 20, 343-349, doi:10.1079/SUM2004267.

Renard, K.G., Foster, G.R., Weesies, G.A., McCool, D.K., Yoder, D.C., 1997. Predicting Soil Erosion by Water: A Guide to Conservation Planning with Revised Universal Soil Loss Equation (RUSLE). USDA Agric. Handbook, vol. 703. U.S. Gov. Print. Office, Washington, DC, doi:10.2489/jswc.63.6.542.

Ritchie, J.C., Nearing, M.A., Nichols, M.H., Ritchie, C.A., 2005. Patterns of soil erosion and redeposition on Lucky Hills Watershed, Walnut Gulch Experimental Watershed, Arizona. Catena 61,122-130, doi:10.1016/j.catena.2005.03.012.

Ruiz Sinoga, J.D., Martinez Murillo, J.F., 2009. Hydrological response of abandoned agricultural soils along a climatological gradient on metamorphic parent material in southern Spain. Earth Surface Process and Landforms 34, 2047-2056, doi:10.1002/esp. 1890

SAS Institute, 2002. The SAS System for Microsoft Windows. Release 8.2. SAS Institute, Cary, NC.

Schnabel, S., 1994. Using botanical evidence for the determination of erosion rates in semi-arid tropical areas. Advances in GeoEcology 27, 31-45, doi:10.1016/ j.catena.2009.02.015.

Shrestha, D.P., Yazidhi, B., Teklehaimanot, G., 2004. Assessing soil loss using erosion models and terrain parameters: a case study in Thailand. In: 25th ACRS 2004, Chiang Mai, Thailand. , doi:10.1016/j.biosystemseng.2009.12.015 pp. 10931098.

Soil Survey Staff, 2006. Keys to Soil Taxonomy, 10th ed. U.S. Gov. Print. Office, Washington, DC

Steenwerth, K.L., Belina, K.M., 2008. Cover crops and cultivation: impacts on soil n dynamics, nitrous oxide efflux, and microbiological function in a mediterranean vineyard agroecosystem. Applied Soil Ecology 40 (2), 370-380, doi:10.1016/ j.apsoil.2008.06.004

Stevens, C.J., Quinton, J.N., 2008. Investigating source areas of eroded sediments transported in concentrated overland flow using rare earth element tracers. Catena 74 (1), 31-36, doi:10.1016/j.catena.2008.01.002.

Vanwalleghem, T., Laguna, A., Giraldez, J.V., Jimenez-Hornero, F.J., 2010. Applying a simple methodology to assess historical soil erosion in olive orchards. Geomorphology 114, 294-302, doi:10.1016/j.geomorph.2009.07.010.

Walkley, A., Black, I.A., 1934. An examination of Degtjareff method for determining soil organic matter and a proposed modification of the chromic titration method. Soil and Science 34, 29-38.

Walling, D.E, He, Q., 1999. Using fallout lead-210 measurements to estimate soil erosion on cultivated land. Soil Science Society of America Journal 63, 1404-1412, doi:10.1016/S1002-0160(07)60034-4.

Wang, G., Gertner, G.Z., Liu, X., Anderson, A.B., 2001. Uncertainty assessment of soil erodibility factor for revised universal soil loss equation. Catena 46, 1-14, doi:10.1016/S0341-8162(02)00198-4.

Wischmeier, W.H. Smith, D.D. 1978. Predicting rainfall erosion losses-a guide to conservation planning. Agriculture Handbook 537 , doi:10.2489/jswc.65.5.267.

Wu, R., Tiessen, H., 2002. Effect of land use on soil degradation in Alpine grassland soil China. Soil Science Society of America Journal 66, 1648-1655, doi:10.2136/ sssaj2002.1648. 